\title{
JUST WAR IN THE CLASSICAL WORLD: GREECE AND ROME
}

\begin{abstract}
War is hell' is one of the mantras used to offer an explanation for the lack of ethical guidance in the radical antagonism involved in that human conflict known as war. Throughout the history of mankind, there has been an effort to introduce ethical considerations in war-waging. However, humanity has assisted, defenseless, to the greatest injustices and disasters once and again. This situation highlights the problematic issues and paradoxes of the concept of "just war". Our purpose here is to analyze the origins of this concept in the Greek ethical reflection during the Peloponnesian War and in the justification of the Roman expansion during the founding of the Roman Empire.
\end{abstract}

Keywords: just war, philosophy, Peloponnesian war, Roman imperialism, Cicero, Thucydides

1. Introduction. 2. Critical reconsideration of just war in ancient Greece. 3. Just war as a justification of Roman imperialism. 4. Conclusion.

\section{INTRODUCTION}

The concept of "just war" can be considered in itself as a contradictio in terminis, since it seems there is no place for justice in the radical antagonism that war implies. However, attempts to shape the idea of just war have been a constant during the last XXII centuries, trying to introduce critical reasoning where there seems to be only place for injustice, wrong and outrage. Nevertheless, the purpose of this paper is to outline two different sets of considerations or ideas about war and its justice in the classical world. We will be dealing with two different stances. On the one hand that of the Greeks in the fifth century B.C., who were engaged in a bloody civil war. On the other hand we will focus on the Romans in the first century B.C., who were building an empire. Despite the considerable lapse of time 
between these two events, there are some moral similarities that we will highlight in due course.

The original sources of information, Thucydides and Cicero, wrote their own analysis of the question of war and justice. Compared to Herodotus (the other great historian of classical Greece), Thucydides' analysis offers a number of benefits from a contemporary perspective: he is more rigorous and tries to be more objective by confronting different opinions. Cicero, on the other hand, is honest in his presentation. He doesn't try to introduce exogenous elements in the concept of war for hegemony or domination. One challenging task facing us today is to settle whether the situation has changed or not.

\section{CRITICAL RECONSIDERATION OF JUST WAR IN ANCIENT GREECE}

The Peloponnesian war was a civil war that lasted almost three decades. To my knowledge it is one of the first civil wars for which we have a detailed chronicle, recorded in Thucydides' magnificent book: The Peloponnesian War ${ }^{1}$. Thucydides (unlike Herodotus, ${ }^{2}$ the other great historian of the classical period) provides an account that offers a number of advantages from a contemporary perspective: he is more rigorous and attempts to be more objective by comparing different opinions. Clear, tangible evidence of his rigor and precision can be found in the texts about the Mytilene episode quoted below.

Let's move directly on to the main topic of this paper, i.e. the issue of war and its justice in the classical world, beginning in this section with Ancient Greece. By way of background, in the midst of the fratricidal conflict between Athens and Sparta the other Greek poleis did not have any choice but to take up a stance in the unavoidable polarization of a conflict with such characteristics. We will not discuss the reasons for this antagonism, the imperial interests of Athens or

1 Thucydides, The Peloponnesian War, Oxford 2009.

2 Herodotus, The Histories, London 2003. 
the Spartan idea of instituting oligarchies throughout the whole Hellas. What is interesting to us here is a specific episode of this war, which is highly paradigmatic of the understanding of war that the Greeks used to have. It is an event that has not been taken into account very often in the scholarly literature, and I am going to call it The Repression of Mytilene. ${ }^{3}$

Mytilene was a Greek polis in the Lesbos Island, and an ally of Athens at the beginning of the hostilities. Allegedly, a Spartan agent called Saleto managed to persuade part of the population to rise up against Athens. The Athenians were very concerned about this situation and sent general Paches to reestablish normality in Mytilene and the entire island of Lesbos. Paches defeated the Mitylenaeans, conquered the city, arrested Saleto and sent him to Athens together with other citizens whom he thought responsible for the uprising, waiting for orders from the Athenian assembly to proceed with the Mitylenians.

The series of events that took place in the Athenian assembly when Paches' ships docked in the city port is what matters most here and may raise our interest in a better understanding of Greek war. Soon enough, the Athenians killed Saleto (the Spartan agent) and "they debated what to do with the other men, and in their state of anger they decided to kill not only the Mytilenaeans they had in Athens but also every adult male in Mytilene, and to enslave the children and women. They thought the offence of revolt was aggravated by the fact that, unlike the others, this was not a revolt from subject status." This form of punishment was the harshest that could be expected . What is missing here is that children were separated from adults and placed close to the wheel of a cart. Then, the taller ones would be put

3 Michael Walzer paid attention to the main topic of the Melian Dialogue, but overlooked the Mytilene episode. See M. Walzer, Just and Unjust Wars, New York 2006, 5-13.

4 Thucydides, op. cit., 145. 
to the sword ${ }^{5}$. Mothers and their children were also sold as slaves in far apart places. Destruction of the very foundations of the city and sowing the fields with salt were also part of this type of full penalty. A trireme with these orders for Paches was sent to Mytilene. The orders ought to be executed immediately. "On the next day there was an immediate change of heart. On reconsideration the Athenians thought it a savage and excessive decision to destroy a whole city rather than just the guilty [of the uprising]."' This reassessment of the decision made by the assembly may seem laudable and characteristic of an advanced, democratic and human community as was Athens in the fifth century B.C. However, as we shall see the true reasons for it were not entirely kind, but selfish. Before moving on to the response to the new debate in the assembly, it is worth exploring the positions that were defended that day. On the one hand there was Cleon urging to follow orders and destroy Mytilene. In defense of this position, he pronounced a very eloquent speech: "I have often thought on previous occasions that democracy is incapable of running an empire (...) Worst of all for us will be if there is no constancy in our decisions, and if we forget that imperfect laws kept valid give greater strength to a city than good laws unenforced. The good sense which comes with intellectual naivety is a more valuable quality than the sophistication which knows no morals, and generally it is the ordinary folk who make the better citizens compared with their cleverer fellows (...) With reckless confidence in the future, and hopes which exceed their capability but still fall short of their ambition, they have declared war. They have seen fit to promote force over justice, choosing to attack us at what they thought would be the moment of

5 This way to distinguish between children and adults in order to select them for punishment can seem cruel and barbaric, or at least a relic of the past. However, during the recent conflict in the former Yugoslavia in the 90's, the Serbians examined whether children had pubic hair in order to differentiate them from adults. Unfortunately, it is clear that old methods of punishment are still carried out today.

6 Thucydides, op. cit., 145-146. 
their advantage, not for any wrong done them by us (...) That was my contention on the first occasion, and it is my contention now that you should not reverse what you have already decided. I urge you not to fall victim to the three things most prejudicial to empire pity, addiction to argument, and fairness. Pity is properly reserved as a mutual obligation between people of like mind, not for those who will show no pity themselves and are necessarily in a state of constant hostility. The politicians who delight us with their arguments can still play their games over matters of less importance, but must not be allowed to do so on an issue which will cost the city dear for the cheap pleasure of listening to them, while they themselves take a fancy reward for a fancy speech. And fairness is the way to treat those who will become and remain our friends, not those who will stay as they were, just as much our enemies as before. I make this one point in summary. If you follow my advice, justice will be done to Mytilene and your own advantage thereby served: if you decide otherwise, it will be less of a kindness to them than a sentence passed on yourselves. If they were right to revolt, you must be wrong to rule them."

It is fair to acknowledge the brilliant oratory shown by Cleon. He defends strongly and skillfully the idea that it is necessary to end Mytilene and destroy it completely. He even mentions that Mitylenians have negated justice with the use of force. This is the first mention of the word 'justice' in this episode. What is appalling in this respect is that Cleon thinks it is fair to raze to the ground the rebel city of Mytilene and subjugate its citizens. Let's consider the opinion of his opponent in the assembly of Athens that day, and whether or not he introduces any idea of justice. After Cleon, Diodotus took the floor. The day before he seemed (but was not) the Proxenus ${ }^{8}$ of

7 Ibidem, 146-149.

8 The Proxenos was an ambassador representing a polis. Usually, the Proxenos was not from the city he represented. Often, he was from the city in which he lived and where he 
Mytilene in Athens, and opposed the killing of the Mitylenians. His magnificent oration begins as eloquently as Cleon's: "I have no criticism of those who have proposed a review of our decision about the Mytilenaeans, and no sympathy with those who object to multiple debates on issues of major importance. In my opinion the two greatest impediments to good decision-making are haste and anger. Anger is the fellow of folly, and haste the sign of ignorance and shallow judgement. Anyone who contends that words should not be the school of action is either a fool or an interested party - a fool, if he thinks there can be any other way of elucidating a future which is not selfevident; an interested party, if with a discreditable case to promote he recognizes the impossibility of a good speech in a bad cause and relies on some good slander to bully both opposition and audience."

Diodotus' beginning is brilliant and passionate. With the clear objective of having the orders from the previous day revoked, he continues his intervention: "I am here before you neither as the advocate of the Mytilenaeans nor as their prosecutor. On any sensible view the question at issue for us is not their guilt but the wisdom of our response." ${ }^{10}$ And here comes one of the moral keys of the whole episode: "I might prove them completely guilty, but I would not for that reason urge their execution if it is not in our interests: I might point to mitigating factors, but would not therefore recommend sparing them unless that is clearly to the good of our city." ${ }^{\prime 11}$ The interest and benefit for Athens is what will determine the future of Mytilene: not human concerns, pity or compassion, but the interests for war. According to this notion of justice, victory is above everything else: achieving the ultimate goal of an armed conflict is literally

defended the interests of another city or polis with which he had family ties or hospitality bonds. However, as we have mentioned Diodotus was not the Proxenos of Mytilene in Athens.

9 Thucydides, op. cit., 150.

10 Ibidem, 151.

11 Ibidem. 
incompatible with any mention of Themis. In other words, justice is relegated to war. It is obviously morally complex to think of the concept of "just war" in these terms. ${ }^{12}$ The argumentation of Diodotus continues as follows: "I believe that the decisions we should be taking are more about the future than the present. And on the very point of Cleon's insistence, that our future interest will be served by imposing the death penalty as a means of preventing further revolts, I too reason from our future security and insist on the opposite conclusion. I beg you not to reject the practicality of my argument for the specious appeal of his. In your present anger at Mytilene you might think his argument has the attraction of justice. But we are not at law with them, so justice is not in point: we are deliberating how to deal with them to our practical advantage." 13

In this last sentence summarizes the idea that we have been exposing: the issue at stake does not concern justice, but a decision to be made regarding Mytilene that is useful. And now Diodotus openly declares the goal of his defense to withdraw the orders to execute all Mitylenians: "In the cities of Greece the death penalty is prescribed for many offences less serious than this and bearing no comparison to it. Even so, hope still induces men to take the risks, and no one has ever embarked on a dangerous scheme in the conviction that he will not survive it (...) So either we must find some still more powerful deterrent, or at least recognize that this deterrent has no effect. Poverty leading through sheer necessity to the courage of desperation; power leading through presumptuous pride to the greed for more; these and the other conditions of life which hold men in the grip of particular passions drive them with an irresistible and overmastering force into dangerous risks (...) We should not,

12 This statement, which in some ways may seem excessive is one of the Basic theses that we defend here. There is no justice in war; this concept was formulated as a justification for its excesses.

13 Thucydides, op. cit., 151. 
therefore, allow any belief in the supposed efficacy of the death penalty to distort our judgement, nor should we leave rebels no hope of an opportunity to change their minds and make swift amends for their offence. Consider how things are now: if a city does start a revolt and then recognizes that there is no chance of success, it can come to terms when it is still able to refund our expenses and continue to pay tribute in future. But if we go the other way, do you not think that all will make more thorough preparations than they do at present, and hold out to the very last under siege, if there is one and the same result whether they submit early or late? And how can it not be damaging to us to sit there spending money on a siege without the possibility of terms, and then, if we capture the place, to take over a ruined city, thus losing all subsequent revenue from it? This revenue gives us our strength against the enemy. 'So rather than judging the off enders by the strict letter of the law, to our own detriment, we should seek to ensure by moderation in our punishment that in time to come we still have the financial resource of allied cities capable of their contribution. For our mode of control we should not rely on the rigour of law, but on practical vigilance."14

In conclusion, Diodotus' argument is that it is not worth terminating the Mitylenaeans because this may alarm other poleis that are in a similar situation. With the expectation of being razed and destroyed by Athens, they may endure to the very end and not easily give up if they are to fear the same punishment as Mytilene. Morality and justice have no place in this speech. However, one might argue that it still serves Themis (the goddess of justice) if the outcome of the debate is a withdrawal of the terrible orders carried by the triremes already underway to Mytilene. But Diodotus' conclusion, interpreted in the right way, shows that that is not the case: "Consider too a further great error you would make if persuaded by Cleon. At present the common people in all the cities are on your

14 Ibidem, 152. 
side. Either they refuse to join the oligarchs in rebellion, or, if they are forced to do so, they immediately form a potential opposition to the rebels: so when you move to war against an apostate city you have the populace as your allies. If you destroy the common people of Mytilene, who had no part in the revolt and once they were in possession of arms took their own decision to hand the city over to you, you will first of all commit the injustice of killing your benefactors, and secondly you will put the ruling classes in exactly the position they want: when they take their cities into rebellion they will then immediately have the common people on their side, since you will have given advance notice that the same penalty applies indiscriminately to the guilty and the innocent. Even if they were guilty, you should pretend otherwise, to avoid turning into enemies the one class of people who are still our allies." ${ }^{15}$

One would expect, as in the usual filmic rhetoric, the Athenian assembly to openly show preference for the opinion of Diodotus. However, this was not the case: "With the two views expressed so evenly matched the Athenians continued to agonize over the decision and the final show of hands was very close, but Diodotus' motion was carried." ${ }^{16}$ Mytilene was saved by a narrow margin. Another trireme was quickly sent to avoid that the new orders reached a city already destroyed. Fortunately for the Mitylenaeans, the second ship arrived just when the Athenian general Paches was preparing to enforce his original orders. ${ }^{17}$

15 Ibidem, 153.

16 Ibidem.

17 Thucydides concludes the narration of this episode as follows: "At one they sent out another trireme urgently, hoping that it would not arrive after the earlier ship and find the city destroyed: the first trireme had a lead of about a day and a night. The Mytilenaean envoys supplied wine and barley-meal for the ship and promised large rewards if they made it in time. Such was the urgency of the voyage that they continued to row as they ate, barley-meal kneaded with wine and oil, and took it in turns to sleep while others rowed on. By good fortune there was no contrary wind. With the first ship in no hurry on its horrible mission, and this second ship speeding in the way described, the result was 
A few years after the repression of Mytilene, a similar episode involved Melos. Thucydides describes it in a few lines at the end of book V: "About the same time the Melians again took another part of the Athenian lines which were but feebly garrisoned. Reinforcements afterwards arriving from Athens in consequence, under the command of Philocrates, son of Demeas, the siege was now pressed vigorously; and some treachery taking place inside, the Melians surrendered at discretion to the Athenians, who put to death all the grown men whom they took, and sold the women and children for slaves, and subsequently sent out five hundred colonists and inhabited the place themselves." 18

The Melians were less fortunate and probably paid for the setbacks that the war was bringing to the Athenians. There was no discussion at the assembly in Athens on the future of Melos.

\section{JUST WAR AS A JUSTIFICATION OF ROMAN IMPERIALISM}

The conception of war that took over Roman culture is different from its Greek counterpart. Rome seemed concerned about providing an ethical component to armed confrontation, including trying to find a justification for the expansion of its legions by force. Here we will only consider the opinion of Cicero on just war. Cicero deals with this issue in some of his works including $\mathrm{O} n$ the Republic, in which he makes the following remark: "Tulio Hostilio created the law governing the declaration of war, and this holly institution in itself consecrated in the College of Fetial, so that if the war had not been

that the first ship arrived just enough ahead for Paches to have time to read de decree and prepare to carry out the decision, but then the second ship put in shortly after and prevented the slaughter. This was how close Mytilene came to destruction" (Ibidem, 154). It must be noted that those responsible for the revolt sent with the Spartan agent Saleto were executed (around one thousand people) and that the walls of Mytilene were destroyed.

18 Ibidem, 307. 
declared and intimated, it was taken as unjust and impious. ${ }^{19}$ In other words, the justice of war is determined by its declaration. Warnings of impending hostilities legitimate a confrontation, regardless of their motives or purposes ${ }^{20}$. The Japanese, who traditionally did not notify nor declared war before their first attack (take, for example, the Russian-Japanese war of 1905 or the attack on Pearl Harbor in 1941), would be outlaw warriors under this roman canon.

We can elaborate more on Cicero's view: "Wars started without a cause are unjust. A war cannot be made just if it is not intended to avenge an insult or to avenge the enemy (...) No war is considered just if it has not been declared and announced, or if the appropriate proclaims have not been made." ${ }^{21}$ This passage adds to the view of justice just outlined the need to avenge an insult or repel an attack, so that justice goes through in antagonism ${ }^{22}$. I can think of several objections to this account that I shall discuss. In philosophical terms, something contingent is not necessary. The concept of justice cannot be contingent, otherwise we would have to deal with a variable and opportunistic right that lacks any value for humans. War, however, has an inexorable aim that cannot be withdrawn: victory, the elation of overcoming. Occasionally, the need to achieve victory will be contingent and change according to the circumstances. In such a case, if we assume that there is a ius in bello, this will become incompatible with the very idea of justice because of its contingency and variability. Furthermore, if victory is so terribly invariable and necessary is its pursuit, such a ius in bello is going to be nothing more than "a series of prudential recommendations similar to the advice designed to mitigate to the most the personal discretion in

19 Cicero, The Republic, Oxford 2009, book II, 17, 31. The fetial were priests endowed with special powers only in the case of a declaration of war. For more information on these priests, see G. Hacquard, Guía de la Roma Antigua, Madrid 1995, 92-94.

20 A. Cruz Prados, La razón de la fuerza, Madrid 2003, 140.

21 Cicero, op. cit., book III, 23, 35.

22 A. Cruz Prados, op. cit., 140-141. 
the proceedings."23 As I see it, these "prudential recommendations" do not fit the concept of justice and the expression ius in bello itself seems to lack real meaning. If so, it has a meaning that is remote from the concept of a pure ius. In other words, the concept appears to be $a d$ hoc and with a certain opportunistic character that gives the impression of an attempt to provide legitimacy to war. Legitimacy that only the winner achieves completely, as history has shown.

Another issue that emerges from reading Cicero is that the justice of war is determined by a deep respect for the fetial ritual: "Roman fetial laws appropriated the principles required to consider just a war. The first two required that war will always be preceded by a formal declaration, and that a prior complaint of violated rights must be done. ${ }^{24}$ Scrupulous obedience to a system administered by priests was the condition without which all legitimacy would be lost. It was first of all necessary to warn the potential rivals about the requirements, and wait for their response. In case they wouldn't pledge to Rome's authority, it was possible to declare war, invoke god Janus in his temple and open its doors (which wouldn't be closed until the war was over) to indicate that war was declared. This ought to be done so that a war could be considered just with regard to religion and forms. Nothing is said about its motivation. What does Cicero say about the legitimate reasons for war? Interestingly, he makes the following claim: "As for war, humane laws touching it are drawn up in the fetial code of the Roman People under all the guarantees of religion; and from this it may be gathered that no war is just, unless it is entered upon after an official demand for satisfaction has been submitted or warning has been given and a formal declaration made." ${ }^{25}$ As we can see, there is no mention of the legitimacy of certain purposes over others. It could not be otherwise in a period in which Rome was

23 R. Sánchez Ferlosio, Sobre la guerra, Madrid 2007, 293.

24 Cicero, On obligations, Oxford 2008, book I, 11, 36.

25 Ibidem, book I, 11, 34. 
forging its imperial domination of most of the known world. The most we can find in Cicero is a demand for full rigor in complying with the rules: "But when a war is fought out for supremacy and when glory is the object of war, it must still not fail to start from the same motives which I said a moment ago were the only righteous grounds for going to war. But those wars which have glory for their end must be carried on with less bitterness. For we contend, for example, with a fellow-citizen in one way, if he is a personal enemy, in another, if he is a rival: with the rival it is a struggle for office and position, with the enemy for life and honour. So with the Celtiberians and the Cimbrians we fought as with deadly enemies, not to determine which should be supreme, but which should survive; but with the Latins, Sabines, Samnites, Carthaginians, and Pyrrhus we fought for supremacy." ${ }^{26}$

Cicero is honest in his statement. He did not attempt to introduce exogenous elements in the concept of war for hegemony or domination. What remains to be assessed today is whether the situation has changed ${ }^{27}$.

\section{CONCLUSION}

As we have seen in the previous pages, it is philosophically difficult to approach the concept of a Just War without facing its contradictions. We have discussed two different sets of considerations on war, namely the Greek and Roman accounts, which lay the groundwork for our own view. Both of them demonstrate that moral limits are frequently transgressed to achieve the main goal during a conflict: victory. Moral rules do exist to be respected. If we willingly ignore such rules to achieve victory over our enemies, we have to admit that morality is

26 Cicero, On obligations, op. cit., book I, 12, 38.

27 See, for example, G. Bouthoul, Tratado de Polemología, Madrid 1984. 
contingent on victory and, if so, a concept such as that of a Just War is a "contradictio in terminis", a vacuous idea and an empty proposition.

Moral philosophers strive to hold moral standards and to prevent injustice in an armed conflict. But we have seen that such attempts do not achieve their objective and are doomed to fail since wars continue to imitate the models that the Greeks and the Romans elaborated according to their own theoretical approaches to the radical antagonism that is war.

\section{BIBLIOGRAPHY}

Bouthoul G., Tratado de Polemología, Ediciones del Ejército, Madrid 1984.

Cicero, On obligations, Loeb Classical Library, Cambridge (MA) 2008.

Cicero, The Republic, Oxford World's Classics, Oxford 2009.

Cruz Prados, A., La razón de la fuerza, Pearson, Madrid 2003.

Hacquard G., Guia de la Roma Antigua, Palas Atenea, Madrid 1995.

Herodotus, The Histories, Penguin, London 2003.

Sánchez Ferlosio R., Sobre la guerra, Destino, Madrid 2007.

Thucydides, The Peloponnesian War, Oxford University Press, Oxford 2009.

Walzer M., Just and Unjust Wars, Basic Books, New York 2006.

Manuel Bermúdez Vázquez

manuel.bermudez@uco.es

University of Cordoba, Faculty of Philosophy and Letters

Plaza Cardenal Salazar, s/n, 14071 Córdoba, Spain

DOI: 10.21697/spch.2017.53.3.02 